\title{
Changes in the ways of life of farmers in the northwest of Portugal after 1980'
}

\author{
Ana Louise de Carvalho Fiúza ${ }^{2 *}$, Maria Johanna Schouten ${ }^{3}$, Neide Maria de Almeida Pinto ${ }^{4}$
}

$10.1590 / 0034-737 X 201663010002$

\begin{abstract}
This study analyzes the changes from 1980s in the lifestyles of families of pluriactive and exclusively agricultural farmers in the northwest of Portugal caused by the income arising from the migration of at least one member of the family to another country in the European Union and the narrowing of the labor and consumer markets among the villages, towns and cities. The theoretical framework used to analyze the changes in the way of life of the pluriactive farmers was based on Giddens' theory of structuration, which denies both the absolute determinism of the structure on the subject and the freedom of unrestrained action of these same subjects. The study was carried out with the application of a survey to 78 farmers, divided into "pluriactive" and "exclusively agricultural" farmers. The findings pointed out to a greater aquisition of modes of urban life by pluriactive farmers compared with the exclusively agricultural farmers and showed a generational bias in this process of acculturation.
\end{abstract}

Keywords: farmer, pluriactivity, lifestyles, northwest of Portugal.

\section{RESUMO}

\section{Mudanças nos modos de vida dos agricultores do noroeste de Portugal após 1980}

Este estudo analisa as mudanças nos modos de vida das famílias de agricultores pluriativos e exclusivamente agrícolas do noroeste de Portugal, a partir dos anos 1980, mediante a obtenção de rendimentos oriundos da migração de, pelo menos, um dos membros da família, para outro país da União Europeia, e o estreitamento do mercado de trabalho e do consumo entre as aldeias, vilas e cidades. A concepção teórica utilizada para orientar as análises relativas às mudanças no modo de vida do agricultor pluriativo baseou-se na teoria da estruturação de Giddens, a qual nega tanto o determinismo absoluto da estrutura sobre os sujeitos, quanto a liberdade de ação irrestrita desses mesmos sujeitos. A pesquisa foi realizada por meio da aplicação de um survey junto a 78 agricultores, divididos em "pluriativos" e "exclusivamente agrícolas". As conclusões apontaram para uma maior apropriação dos modos de vida urbano pelos agricultores pluriativos, quando comparada com a dos exclusivamente agrícolas, bem como evidenciaram um viés de geração neste processo de aculturação.

Palavras-chave: agricultor, pluriatividade, modos de vida, noroeste de Portugal.

\footnotetext{
Submitted on 04/15/2014 and approved on 10/12/2015.

1 This work results from the first author's post-doctoral research at the Universidade do Minho, in Portugal, in 2013.

${ }^{2}$ Universidade Federal de Viçosa, Departamento de Economia Rural, Viçosa, Minas Gerais, Brasil. louisefiuza@ufv.br

${ }^{3}$ Universidade da Beira Interior (Covilhã), Departamento de Sociologia; Universidade do Minho, Portugal. schouten@sapo.pt

${ }^{4}$ Universidade Federal de Viçosa, Departamento de Economia Doméstica, Viçosa, Minas Gerais. Brasil. nalmeida@ufv.br

* Corresponding author: louisefiuza@ufv.br
} 


\section{INTRODUCTION}

The objective of this study was to analyze the changes in the living conditions of families of full-time farmers and pluriactive farmers in a context of narrowing relationship between labor and life among the villages, towns and cities in the northwest of Portugal. Observing the changes occurring in the Portuguese agriculture from 1960 to 2010, it is clear that in these five decades there was a rapid and drastic transformation, not only of the agricultural practice, but also the way of life of farmers. However, while studies related to changes in the agrarian structure and production are numerous, particularly in the field of Economics and Sociology, questions concerning the role of this pluriactive agriculture in the life and the daily lives of farmers have been limited to few scattered studies, from the 1980s to present day, including the works of Cavaco (1980), Cepeda (1988), Villanova et al. (1995), Silva (1998), Wall (1998), Ferro (2006), Devens (2007), Babo (2012) and Fischer \& Burton (2014).

The Portuguese agricultural productivity and census estimates, according to Silva et al. (2012), showed a continuous decrease in the number of farms and declined by almost half in forty years, dropping from 853,568 to 446,146 in the period from 1954 to 1994 . Particularly the Minho region in northwest Portugal, locus of this study, clearly shows the marks of urbanization of the rural society. In this region, until the late 1970 s, the presence of peasants who lived on subsistence farming was significant in their villages. Today, Minho villagers increasingly enter the labor and consumer markets, including food consumption. This reality follows a global trend also reported by Silva (2013), in relation to the reduction of the workforce in agriculture, in Portugal, which in 1979 was close to 50\%, falling in 2010 to $10 \%$. However the lifestyles in the Minho's villages also changed in terms of community relations, which have become more individualized. As the non-farm work in towns or cities in the surrounding villages or the migration of a family member abroad advanced from the 1980s, the reciprocal relations among the villager farmers were being replaced by other based on the monetization of the way of life. This study aims mainly to understand the changes in the way of life of pluriactive farmers, a category expanding in the agriculture practiced not only in the Minho villages in northwest Portugal, but in most of the Western world.

This study was conducted in the municipality of Vila Verde, which belongs to the district of Braga, northwest of Portugal, with an area of 228.67 square kilometers divided into 58 parishes (villages). According to data from the National Statistics Institute of Portugal (INE), in 2011, Vila Verde had 47,888 inhabitants and a population density of 209 inhabitants $/ \mathrm{km}^{2}$. The population, unlike many
Portuguese municipalities, has increased census after census, albeit in a minor way. Vila Verde follows the demographic dynamics of the Cávado and Ave region, which, according to data from INE (2011), have a high population density and a considerable population growth, following the most significant trend in the northern region, which has the highest birth rates and lower mortality among the regions of Portugal.

The number of women in the population became greater than men: with 24,943 women and 22,945 men. Men with no education are fewer in number and percentage than women: $1,820(8 \%)$ and 3,099 (12\%), respectively. Considering the population in general, the most prevalent level of education was the primary education, which means nine years of study. This was the level of education of 14,779 women, representing $59 \%$ of the population, and 15,404 men, $67 \%$. Increased education is evident when comparing the new with the oldest generations. This level of schooling rises together with the increasing age of the first marriage, both among men and women. Silva et al. (2012) composed a comparison table for the age of the first marriage between the years of 1970 and 2011, based on INE data, and found an increase in the age of the first marriage, both among men and women: from 26.6 to 31 years of age among men, and 24.3 to 29.5 years of age among women. Another socio-demographic characteristic of the population is aging. The average age of the population in 2001 was 33.42 years, increasing to 36.16 years in 2011. In the comparison made by Silva et al. (2012: 9) with INE data from 1970 and 2011, "the life expectancy of men rose from 64 years in 1970 to 76.4 in 2010, and increased from 70.3 years to 82.3 years for women over the same period (INE, Deaths Statistics)" (Pordata, 2012, cited by Silva et al., 2012, p. 9). If today people die later in northern Portugal, in comparison with the 1970s, they also die much less at birth. As it was quoted by Silva (2012, p. 8): "There was a spectacular reduction in infant mortality in Portugal from 55.5\%o in 1970 to $3.1 \%$ in 2011" (Pordata 2012 cited by Silva et al. 2012, p. 8).

The population dynamics observed in much of northern Portugal, especially in the Cávado and Ave region, also reflects the industrialization rates achieved in the period following the 1980s. The economy of the primary sector is little significant compared to the secondary and tertiary sectors. Although agriculture is practiced all over the northern region, even in the most urbanized areas of towns and cities, only the tertiary sector grew in the decade of 2001-2011. With regard to the socioeconomic dynamics of the municipality studied in the Minho region, the employment rate fell from 49 to $46.4 \%$, from 18,504 to 18,357 people employed, while unemployment remains rising census after census: $4 \%$ in 1991, 5.4\% in 2001 and rising 
to $12.88 \%$ in 2011 , with 2,736 people unemployed. Therefore, one might have expected that also the population's purchasing power had fallen, as shown by Silva et al. (2012).

It is therefore clear, that the northwest of Portugal has undergone profound changes since the decade of 1980. Silva et al. (2012) described the Minho region, from that decade, as increasingly marked by continuities between rural and urban. The author stated that this region was strongly impacted by the urbanization process, the penetration of new technologies and the regulatory and absorbig role, not only of the Portuguese State, but also the European Union agencies (Silva et al., 2012, p. 5). Thus, also the way of life of farmers living in Minho villages in the northwest of Portugal has undergone obvious changes between the 1980s and the present day, pointing out, greatly, the narrowing of the labor and product markets among the villages, towns and cities.

The concept of pluriactivity by Carneiro $(2006,2012)$ was used in this study because the objective of this research was to analyze the changes in the living conditions of the families of full-time farmers and pluriactive farmers, who combined agriculture with other non-agricultural activities, in a narrowing environment between villages and towns and cities. The author discusses that pluriactivity is not just the combination of agricultural and non-agricultural, which is characteristic of contexts marked by socio-economic diversification. She found that the combination of agricultural with nonagricultural activities has always existed and it was perfectly contemplated, in analytic terms, with the concept of part-time farming (Carneiro, 2006, 2012). She claims that pluriactivity assumes a combination of agricultural and non-agricultural activities, but within a context of economic dynamism, which provides an intertwining of consumer and labor markets between the countryside and the city, providing opportunities to individuals from agricultural families to work in non-agricultural activities and invest the income from these activities on the farm as well.

In this study, a pluriactive family was considered as that having one of its members engaged in off-farm employment and part of the income earned provided the investment in agricultural or non-agricultural activities carried out by the family. In line with this theoretical concept of pluriactivity, in this research, for better analytical precision of the data, we used the term restricted pluriactivity when only one individual performed nonagricultural off-farm activities, and extensive pluriactivity, when more than a member operated non-agricultural offfarm activity. That means, the term proposed here values the effects of non-agricultural activities carried out outside the farm on the "ways of life" of farmers.
The concept "way of life" was used in the 1950s and 1960s by Candido (1964), Rambaud (1969), Wirth (1979) and Lefebvre (2008) to characterize contexts marked by the effects of the industrialization and urbanization process on the ways of living, working, eating, as well as the access to education and the means of transportation and communication. This whole set of variables, listed by the authors, as constituting the way of life of people, indicates that they begin to integrate increasingly the consumer society, in a context of urbanization of rural societies. However, these changes in the ways of life of human groups in villages, towns and cities did not occur in the same way and at the same time. The industrialization of agriculture in the Minho villages was not the greatest responsible for causing changes in the way of life of farmers, but the cash flow coming from the migration of at least one family member to other EU countries, notably to France, the Netherlands, Luxembourg, England and Germany, as well as the increasing exchange of the labor market among villages, towns and cities in the northwest Portugal.

It was considered, then, that the "way of life" comprises the material and symbolic conditions that underlie the existence of a group or an individual: the cultural practices, the technological devices, the working relationships, the time devoted to work, the leisure activities, etc. The considerations of Guerra (1993) were also taken into account, in which the concept of "way of life" emphasizes three elements still poorly articulated: the system and the actors, the history and the everyday life and the objective and the subjective in the perception of reality. The concept of "way of life" of Guerra (1993) was used in this study because it incorporates the concepts of Candido (1964) and Rambaud (1969), which have a strong confluence with the theory of structuration by Giddens (2009). Based on the theoretical framework used in this study, the following hypothesis was formulated: the expansive force of urban culture manifests itself differently depending on the agricultural exploitation and is more noticeably present in extensive pluriactive agricultural exploitations that keep greater exchange with the city labor market.

\section{MATERIAL AND METHODS}

To analyze the changes in the ways of life of the farmers' families of Minho, northwest Portugal, a threepart survey with 38 questions was applied. The first part consisted of questions concerning the socio-economic structure of the household and favored the collection of data relating to activities performed by each member of that household. The second part consisted of questions related to the physical structure of the house, the living 
conditions and work on the farm. Data were taken on appliances and utensils in the house as well as the tools and technologies used in the agricultural work. The third part of the survey collected information about the way of life of farmers, including the use they made of durable consumer goods such as car, motorcycle and bicycle, as well as equipment related to Information and Communication Technologies, as mobile phone, computer and internet. Questions were made relating to leisure activities and the time devoted to non-work, which were guided by the gender perspective.

Vasconcelos (2002) stated that the survey method is used in studies involving a segment or portion of the population, i.e., an accurately selected sample and statistically planned to be representative of the population from which it is drawn. According to Babbie (2001), the analysis of the survey is divided between the description and the explanation; in this way, the researcher using this method measures the variables and subsequently examines the association between them. Thus, this method allows the estimation of the total population from which the sample was selected. To collect data, we used the semi-structured questionnaire, combining closed and open questions, which allows the participant to discuss the proposed theme without being attached to the formulated question (Minayo, 2012, p. 64).

The municipality of Vila Verde and some villages in its surroundings was chosen as location for the research because of the strong agricultural tradition of this region and the proximity with the University of Minho in Braga, where the study is being developed. Questionnaires were applied in 24 of the 48 parishes that make up the municipality of Vila Verde, i.e., 50\% of the total. In addition to these parishes, questionnaires were applied in three others in the surroundings of Vila Verde, namely Braga, Barcelos and Ponte de Lima. The questionnaires were applied between May and July 2013, by a team of three interviewers: the researcher in charge of the investigation, a veterinarian of an agricultural cooperative and a civil engineer, unemployed, daughter of one of the farmers interviewed. The interviewers were trained for the standardization of application procedures and met weekly to report on the application of the questionnaires.

The sampling was composed of quotas that sought to: 1) maintain as much as possible, the numerical balance between respondents of both genders; 2) characterize the three types of agricultural exploitation which are the focus of this research: exclusively agricultural farms; restricted pluriactive farms and extensive pluriactive farms. A total of 78 questionnaires were applied: 37 with men, accounting for $47 \%$ of the sample, and 41 with women, representing $53 \%$ of the sample. The questionnaires were also almost equally distributed among the three types of farms: $35 \%$ in extensive pluriactive farms; $29 \%$ in restricted pluriactive farms and $36 \%$ in exclusively agricultural farms. A sampling design was chosen to provide closer numbers of men and women, as well as an equal proportion of respondents belonging to each of the three types of farms, aimed at, obviously, to provide a gender-biased analysis, as well as to explore issues relating to ways of life of families belonging to three types of agricultural exploitations.

Responses of the survey were categorized and described in spreadsheets, charts, and tables. After data extraction and organization of categories have taken place, data were inserted in Excel Microsoft Office software and analyzed using the Statistical Package for Social Sciences - SPSS, version 20.0 to carry out the exploratory data analysis - EDA. The EDA described the survey variables and presented the frequencies, percentages, means, minimum and maximum values, among others. The software SPSS was chosen because it is a widely used program for statistical analysis in social science (Martinez \& Ferreira, 2007).

The age classification criterion used in this study followed empirical indicators linked to the ways of life of the individuals, since the variable way of life is central to this study. Thus, the "young adult" age group was considered between the end of high school, around 18 years of age, and the mean age at which men and women marry for the first time, around 30 years of age, according to INE data for the northern region of Portugal. The empirical criterion used for the groups "adult", "mature adult" and "senior" was based on the life cycle of individuals. Therefore, "adults" were those individuals married with young children and with teenagers still living at home and studying; "mature adults" were those individuals married with grown children, living away from home and not studying anymore, and "senior" were those individuals above 65 years of age and retired.

\section{RESULTS AND DISCUSSIONS}

Among the three types of agricultural exploitations studied (exclusively agricultural, restricted pluriactive and extensive pluriactive), the farmers classified as "young adults" or "adults", with ages between 18 and 45, were twice the percentage in "pluriactive" families than in "exclusively agricultural" families. This reinforces the findings of Silva et al. (2012) and Silva (2013), who have shown the growth of pluriactivity among families of farmers of the younger generations that have experienced the largest exchange of the labor market and the market of services and goods among the villages, towns and cities in the region (Table 1).

Analyzing in more detail the types of activity carried out by 262 individuals who composed the 78 families studied, there was, beyond the expected, the existence of 
people who performed non-agricultural activities in the pluriactive families, which means, the importance of agriculture on an individual basis. When considering each of the 262 members of the 78 families surveyed, it was observed that the vast majority of 145 individuals, representing 55\% overall, worked exclusively in agriculture. Thus, if on the one hand, it is significant the percentage of individuals who perform non-agricultural activities in pluriactive families, on the other hand, even among them, the agricultural activity continues to occupy a significant percentage of family members, in general, more women than men (Cepeda, 1988; Villanova et al., 1995). Half of the families interviewed could produce approximately $50 \%$ of the food they consumed, in particular vegetables, fruits, small animals, eggs and wine in small farms. Approximately $80 \%$ of the surveyed farms had no more than five hectares of land (Table 2).

Observing specifically the modes of living of the villagers farmers, there is a resemblance to the urban way of life, which is seen both in the physical structure of the house and the use of appliances, transportation and communication common to city dwellers. The refurbishments carried out in the houses, as in Table 3 and in the testimony of the Interviewed number 11, show a trend in the three types of farms: acceptance of the bourgeois model of separation between public and private spaces in the house, individualization, separating the master's bedroom and children's, as well as the bathrooms between them and the visitors. The ways of being in the home and use it show, besides the appreciation of individuality and privacy, the search for comfort and practicality, which is greatly evidenced in the materials used for decorating floors and walls. The aesthetic appreciation of the worked nature is also introduced in the space reserved for the garden and the surroundings of the house. However, the villager house is home to farmers and, thereby, the land is also target of its inhabitants' investment, indicating the application of the economic resources from the nonagricultural activities that will modernize and boost especially the agricultural practices prior the harvest, since it is not significantly mechanized in the Minho farms (Table 3).

Not only the physical structure of the house underwent the influences of the urbanization process triggered by the dissemination of urban culture and practices, but also the ways of living were impacted by domestic appliances and modern technological artifacts, which pervaded the lives of farmers of the Minho villages. The studies of Vilanova et al. (1995), Wall (1998) and Pereira (2011) show how, from the 1990s, the farm houses have become unrecognizable. Table 4 points out this rigging of farmers' houses. Nevertheless, among the equipment used by the three types of families, the firewood and stove continue to be widely used by all of them, pointing out the maintenance of a typical custom of the rural way of life, however, concomitantly with refrigerator, vacuum cleaner, fixed telephone, mobile phone and even computer and the Internet, which, although less used by exclusively agricultural families, still with a significant percentage (Table 4).

Therefore, the data show that, today, the modern houses of Minho villages have basically the same appliances, technological devices, communication and transportation of the city homes. The significance of this

Table 1: The respondent's age range per type of family

\begin{tabular}{|c|c|c|c|c|c|}
\hline & & \multicolumn{3}{|c|}{ Family type according to activity } & \multirow[b]{2}{*}{ Total } \\
\hline & & $\begin{array}{c}\text { Extensive } \\
\text { pluriactive }\end{array}$ & $\begin{array}{l}\text { Restricted } \\
\text { pluriactive }\end{array}$ & $\begin{array}{l}\text { Exclusively } \\
\text { agricultural }\end{array}$ & \\
\hline \multirow[t]{3}{*}{ Respondent's age range } & $18-45$ & $8(10 \%)$ & $8(10 \%)$ & $4(5 \%)$ & $20(26 \%)$ \\
\hline & $46-65$ & $14(18 \%)$ & $13(17 \%)$ & $9(12 \%)$ & $36(46 \%)$ \\
\hline & $\geq 66$ & $5(6 \%)$ & $2(3 \%)$ & $15(19 \%)$ & $22(28 \%)$ \\
\hline Total & & $27(34 \%)$ & $23(30 \%)$ & $28(36 \%)$ & $78(100 \%)$ \\
\hline
\end{tabular}

Source: Research data, 2013.

Table 2: Type of activity performed per each of the family members

\begin{tabular}{llcccc}
\hline & & \multicolumn{4}{c}{ Family type according to activity } \\
\cline { 3 - 4 } & & $\begin{array}{c}\text { Extensive } \\
\text { pluriactive }\end{array}$ & $\begin{array}{c}\text { Restricted } \\
\text { pluriactive }\end{array}$ & $\begin{array}{c}\text { Exclusively } \\
\text { aggricultural }\end{array}$ & Total \\
\hline \multirow{2}{*}{$\begin{array}{l}\text { Activity performed by each } \\
\text { of the family members }\end{array}$} & Non-agricultural activity & $65(59 \%)$ & $25(29 \%)$ & $0(0 \%)$ & $90(34 \%)$ \\
Total & Only agricultural activity & $34(31 \%)$ & $47(53 \%)$ & $64(100 \%)$ & $145(55 \%)$ \\
& No response & $11(10 \%)$ & $16(18 \%)$ & $0(0 \%)$ & $27(10 \%)$ \\
& & $110(100 \%)$ & $88(100 \%)$ & $64(100 \%)$ & $262(100 \%)$ \\
\hline
\end{tabular}

Source: Research data, 2013.

Rev. Ceres, Viçosa, v. 63, n.1, p. 008-015, jan/fev, 2016 


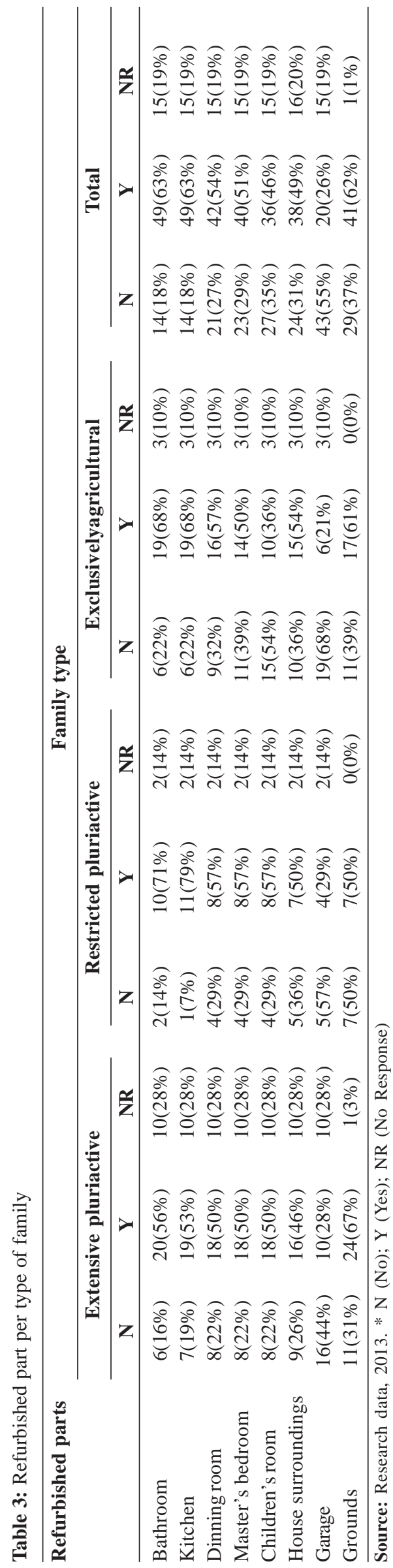

process of rapprochement between rural and urban living conditions shows, for the villagers, the chance to live a life with projects, with transcendence, in relation to the hardships imposed by the reproduction of the rural way of life. A refrigerator enables the planned storage, not only of foodstuff needed for the family's survival, but a variety of meat, poultry, fish, seasonal fruit, etc. The house is no longer a place of shelter for the family and the animals and becomes a place of warmth and comfort, with heating, lighting, private cleaning, entertainment, etc. Communication goes beyond the limits of contact between the villagers and connects those who are integrated into the daily routine of the farm and family, even from abroad. Shifts between village, town and city become part of the routine and cars are present in over $80 \%$ of the three farm types, however, in greater numbers in pluriactive farms, allowing effectively the interaction between individuals living in the villages, towns and cities of this region of northwest Portugal.

\section{CONCLUSIONS}

The analyses of the changes in the ways of life of pluriactive farmers and exclusively agricultural farmers in Minho villages showed that these transformations outlined a phenomenon that is becoming consolidated in northwest Portugal: the existence of agriculture without family of exclusively agricultural farmer. However, if on the one hand, it is undeniable how the way of life of these pluriactive farmers has become urbanized, in particular the housing pattern, the possession of technologies and the access to means of transport, on the other hand, the agriculture practice proves to be adapted to these changes.

Therefore, the changes in the way of life of Minho farmers in northwest Portugal show clearly that agriculture can adapt to the urbanization of ways of life and even exist without full-time farmers. The proximity of the villages to towns and cities has favored the increase of families of extensive pluriactive farmers that continue to practice agriculture, but combined with other activities. Thus, the designation "farmer" may indeed have not defined the identity status of the person who is practicing agriculture, since this practice is no longer exclusively agricultural, although agriculture remains important for the reproduction not only of exclusively agricultural families, but also the pluriactive families. Although, today, these pluriactive farmers have a more urbanized way of life, agriculture proves to be compatible with it. If this agriculture is not economically and productively strong, this is certainly due to the facts that the Minho region is characterized by the predominance of small farms and that Portugal has opted for an agricultural policy that encourages commercial scale agriculture at the expense of small-scale agriculture. 
Ana Louise de Carvalho Fiúza et al.

Table 4: Possession of household technology, communication and transportation

\begin{tabular}{|c|c|c|c|c|}
\hline \multicolumn{5}{|c|}{ Family type, according to activity } \\
\hline $\begin{array}{l}\text { Household } \\
\text { technology }\end{array}$ & $\begin{array}{l}\text { Extensive } \\
\text { pluriactive }\end{array}$ & $\begin{array}{l}\text { Restricted } \\
\text { pluriactive }\end{array}$ & $\begin{array}{l}\text { Exclusively } \\
\text { agricultural }\end{array}$ & Total \\
\hline Fridge (refrigerator) & $36(100 \%)$ & $14(100 \%)$ & $28(100 \%)$ & $78(100 \%)$ \\
\hline Wood burning stove & $22(61 \%)$ & $9(64 \%)$ & $19(68 \%)$ & $50(64 \%)$ \\
\hline Firewood & $25(69 \%)$ & $10(71 \%)$ & $20(71 \%)$ & $55(70 \%)$ \\
\hline Vacuum cleaner & $32(89 \%)$ & $12(86 \%)$ & $26(93 \%)$ & $70(90 \%)$ \\
\hline Telephone & $26(72 \%)$ & $12(86 \%)$ & $17(61 \%)$ & $55(70 \%)$ \\
\hline Mobile phone & $31(86 \%)$ & $13(93 \%)$ & $26(93 \%)$ & $70(90 \%)$ \\
\hline Computer & $28(78 \%)$ & $11(79 \%)$ & $16(57 \%)$ & $55(70 \%)$ \\
\hline Internet & $25(70 \%)$ & $11(79 \%)$ & $13(46 \%)$ & $49(63 \%)$ \\
\hline TV & $34(94 \%)$ & $14(100 \%)$ & $27(96 \%)$ & $75(96 \%)$ \\
\hline Cable TV & $12(33 \%)$ & $3(21 \%)$ & $7(25 \%)$ & $22(28 \%)$ \\
\hline Microwave oven & $29(81 \%)$ & $11(79 \%)$ & $22(79 \%)$ & $62(80 \%)$ \\
\hline Washing machine & $34(94 \%)$ & $13(93 \%)$ & $26(93 \%)$ & $73(94 \%)$ \\
\hline Dishwasher & $12(33 \%)$ & $2(14 \%)$ & $7(25 \%)$ & $21(27 \%)$ \\
\hline Heating & $32(89 \%)$ & $13(93 \%)$ & $25(90 \%)$ & $70(90 \%)$ \\
\hline Fireplace & $28(78 \%)$ & $8(57 \%)$ & $22(79 \%)$ & $58(74 \%)$ \\
\hline Use of fireplace to cook & $19(53 \%)$ & $8(57 \%)$ & $16(57 \%)$ & $43(55 \%)$ \\
\hline Car & $30(83 \%)$ & $12(86 \%)$ & $23(82 \%)$ & $65(83 \%)$ \\
\hline Motorcycle & $13(36 \%)$ & $8(57 \%)$ & $12(43 \%)$ & $33(42 \%)$ \\
\hline Total & $36(100 \%)$ & $14(100 \%)$ & $28(100 \%)$ & $78(100 \%)$ \\
\hline
\end{tabular}

Source: Research data, 2013.

\section{ACKNOWLEDGEMENTS}

This study was financed by CNPq in the part concerning Portugal and by FAPEMIG in the part concerning to the Zona da Mata Mineira. The research as a whole was intended to examine the ways of life of farmers in both realities. Thus, the support of CNPq and FAPEMIG allowed meeting the research objectives.

\section{REFERENCES}

Babbie E (2001) Métodos de pesquisas de survey. Belo Horizonte, UFMG. 519p.

Babo JPM (2012) Moldar o gênero. A construção social do gênero numa aldeia rural do Alto Douro. Dissertação de Mestrado. Universidade do Minho, Portugal. 213p.

Candido A (1964) Os parceiros do Rio Bonito. Estudo sobre o caipira paulista e a transformação dos seus meios de vida. Rio de Janeiro, José Olympio Editora. 336p.

Carneiro MJ (2006) Pluriatividade da agricultura no Brasil: uma reflexão crítica. In: Schneider S (Ed.) A Diversidade na Agricultura Familiar. Porto Alegre, UFRGS. p.96-128.

Carneiro MJ (2012) Ruralidades contemporâneas: modos de viver e pensar o rural na sociedade brasileira. Rio de Janeiro, Mauad X. 268 p.

Cavaco C (1980) A agricultura a tempo parcial. Lisboa, Centro de Estudos Geográficos. 418p.

Cepeda FJT (1988) Emigração, regresso e desenvolvimento no nordeste interior português. Vila Real, Universidade de Trás-osMontes e Alto Douro. 297p.
Devens JO (2007) Agricultura familiar e pluriatividade: atividade rural e domicílio urbano. Dissertação de Mestrado. Universidade Estadual do Oeste do Paraná, Toledo. 94p.

Ferro J (2006) Influência da pluriatividade para a permanência dos agricultores familiares na atividade agrícola e no meio rural: um estudo de caso no município de Concórdia/SC/Florianópolis. Dissertação de Mestrado. UFSC, Florianópolis. 158p.

Fischer H \& Burton RJF (2014) Understanding farm succession as socially constructed endogenous cycles. Sociologia ruralis, $54: 417-438$

Giddens A (2009) A constituição da sociedade. São Paulo, WMF Martins Fontes. 458p.

Guerra I (1993) Modos de vida: novos percursos e novos conceitos. Sociologia: problemas e práticas, 13:59-74.

INE - Instituto Nacional de Estatística (2011) Inquérito à Estrutura das Explorações Agrícolas. Lisboa, Instituto Nacional de Estatística. 54p.

Lefebvre H (2008) A revolução urbana. Belo Horizonte, Editora UFMG. $178 \mathrm{p}$.

Martinez LF \& Ferreira AI (2007) Análise de dados com SPSS: primeiros passos. Lisboa, Escolar Editora. 178p.

Minayo MCS (2012) Pesquisa social: teoria, método e criatividade. $23^{\mathrm{a}}$ ed. Petrópolis, Vozes. 31p.

Pereira SM (2011) Cenários do cotidiano doméstico: modos de habitar. In: Mattoso L \& Almeida NA (Eds.) História da vida privada em Portugal: os nossos dias. Lisboa, Círculo de leitores: Temas e debates. p.16-47.

Rambaud P (1969) Société rurale et urbanisation. Paris, Editions du Seuil. 343p.

Silva MC (1998) Resistir e adaptar. Constrangimentos e estratégias camponeses no noroeste de Portugal. Porto, Edições Afrontamento. 479p. 
Silva MC, Cardoso A \& Ribeiro V (2012) Unequal and Dependent Development: the Minho region in the Northwest of Portugal. Cuadernos de Desarrollo Rural, 9:103-125.

Silva MC (2013) Sócio-antropologia rural e urbana. Fragmentos da sociedade portuguesa (1960-2010). Porto, Edições Afrontamento. 304p.

Vasconcelos EM (2002) Complexidade e pesquisa interdisciplinar: Epistemologia e Metodologia Operativa. Petrópolis, Vozes. $343 p$.
Villanova R, Leite C \& Raposo I (1995) Casa de sonhos: emigrantes construtores no Norte de Portugal. Lisboa, Salamandra. 258p.

Wall K (1998) Famílias no campo. Passado e presente em duas freguesias do Baixo Minho. Lisboa, Dom Quixote. 379p.

Wirth L (1979) O urbanismo como modo de vida. In: Velho Ogo (Ed) Fenômeno urbano. $4^{\mathrm{a}}$ ed. Rio de Janeiro, Zahar Editores. p.90-113. 